\title{
A Preliminary Neuroendocrine Study with Buspirone in Major Depression
}

Frederick G. Moeller, M.D., Joel L. Steinberg, M.D., Mark Fulton, M.D., Gerald Kramer, B.A., and Frederick Petty, Ph.D., M.D.

We administered the serotonin-1a agonist buspirone (0.4 $\mathrm{mg} / \mathrm{kg}$ orally) as a neuroendocrine challenge agent to a group of male patients with DSM-III-R major depressive disorder $(M D D)(\mathrm{n}=13)$ and a group of male healthy controls $(\mathrm{n}=10)$. The primary hypothesis of the study was that the prolactin response to buspirone would be blunted in the depressed patients. The prolactin response was significantly lower in depressed patients than in controls. There was no significant relationship between placebo corrected-peak prolactin level and severity of depression or suicidality. There was a nonsignificant trend for the melancholic $(\mathrm{n}=5)$ depressed patients to have a lower placebo corrected-peak prolactin level than nonmelancholic depressed patients $(\mathrm{n}=8$ ).

Our findings support a role for the serotonin-1a receptor in the etiology of $M D D$, specifically at the postsynaptic site. [Neuropsychopharmacology 10:7583, 1994]
KEY WORDS: Depressive disorder; Serotonin; Buspirone; Prolactin

A specific role for serotonin (5-HT) in the etiology of depression was proposed over 25 years ago (Coppen 1967). The original 5-HT theory of depression postulated a deficit of 5-HT leading to symptoms of depression. Some of the strongest clinical support for a central role for 5-HT in depression comes from the more recent finding that drugs that are selective 5-HT uptake inhibitors, such as fluoxetine, paroxetine, and sertraline are effective antidepressants (Reimherr et al. 1990). Further support for the 5-HT-depression relationship comes from studiesusing the 5-HT neuroendocrine challenge strategy. Using this technique, several authors have interpreted their results as being consistent with

From the Department of Psychiatry and Behavioral Sciences (FGM), University of Texas Houston Health Science Center; the Dallas VA Medical Center (JLS, MF, GK, FP); and the Department of Psychiatry (JLS, MF, GK, FP), University of Texas Southwestern Medical School at Dallas, Texas.

Address correspondence to: Frederick G. Moeller, M.D., Department of Psychiatry and Behavioral Sciences, University of Texas Houston Health Science Center, 1300 Moursund, Houston, TX 77030.

Received May 6, 1993; revised October 28, 1993; accepted November $5,1993$. reduced 5-HT function in patients with depression using 5-HT precursors (Charney et al. 1984; Heninger et al. 1984), 5-HT reuptake inhibitors (Golden et al. 1992), and 5-HT-releasing agents (Siever et al. 1984; Coccaro et al. 1989; Mitchell and Smythe 1990; Lichtenberg et al. 1992; Shapira et al. 1992a, 1992b).

There has been a relatively consistent finding of decreased prolactin response to various serotonergic agents in subjects with major depressive disorder (MDD) using nonspecific 5-HT challenge agents; thus, recent research has focused on the role of specific subtypes of 5-HT receptors in this response and whether the blunted prolactin response is measuring a presynaptic or postsynaptic phenomenon.

Several preclinical lines of evidence support a significant role for the 5- $\mathrm{HT}_{1 \mathrm{a}}$ receptor in MDD. Goodwin and colleagues (1985) found that a variety of antidepressant treatments including selective 5-HT uptake inhibitors, tricyclic antidepressants, monoamine oxidase inhibitors, and electroconvulsive shock all attenuate the presynaptic hypothermic response to the 5 - HT $_{1 \mathrm{a}}$ agonist 8 -hydroxy-2-(di- $n$-propylamino)tetralin (8-OH-DPAT) in the rat. Using electrophysiologic techniques, including measurement of presynaptic firing rate in the dorsal raphe, as well as postsynaptic firing 
rate in the hippocampus. Blier and de Montigny (1990) demonstrated that a variety of antidepressant treatments all increased tonic activation of postsynaptic $5-\mathrm{HT}_{1 \mathrm{a}}$ receptors. Another recent study found that $5-\mathrm{HT}_{1 \mathrm{a}}$ receptor number in the frontal cortex of the rat as measured by $8-\mathrm{OH}$-DPAT binding was decreased by both chronic antidepressant treatment and electroconvulsive shock (Pandey et al. 1991).

This response to antidepressant treatment by the $5-\mathrm{HT}_{1 \mathrm{a}}$ receptor is different from that of the $5-\mathrm{HT}_{2}$ receptor, which is upregulated by ECS and downregulated by antidepressant medications (Peroutka and Snyder 1980). Further preclinical support for a central role for the $5-\mathrm{HT}_{1 \mathrm{a}}$ receptor in MDD comes from the fact that $5-\mathrm{HT}_{1 \mathrm{a}}$ agonists are effective antidepressants in animal models of depression such as learned helplessness and the forced swim test (Wieland and Lucki 1990; Cervo and Samanin 1987; Martin et al. 1990).

Human studies also give some evidence of involvement of the 5- $\mathrm{HT}_{1 \mathrm{a}}$ receptor in patients with MDD. Although the $5-\mathrm{HT}_{1 \mathrm{a}}$ agonist buspirone was originally marketed as an anxiolytic, one study found that buspirone decreased symptoms of MDD (Rickels et al. 1991). More recently, the buspirone analogs gepirone and ipsapirone have also been found to possess some antidepressant effects (Rausch et al. 1990, Amsterdam et al. 1992; Lesch et al. 1991). Two recent neuroendocrine challenge studies using the $5-\mathrm{HT}_{1 \mathrm{a}}$ agonist ipsapirone also lend support for differences in $5-\mathrm{HT}_{1 \mathrm{a}}$ receptor function in MDD. The first study found that the hypothermic response to ipsapirone was attenuated after amitriptyline treatment (Lesch et al. 1990). The second study by the same group found a blunted ipsapirone induced adrenocorticotrophic hormone $(\mathrm{ACTH})$ response in patients with MDD compared to controls (Lesch et al. 1991). Both of these studies are interesting; however, the results of these studies are difficult to interpret in light of the fact that the hypothermic response may be a presynaptic autoreceptor response (Lesch et al. 1991), and the ACTH response is thought to be postsynaptic (Meltzer et al. 1983).

To further examine the role of postsynaptic 5- $\mathrm{HT}_{1 a}$ receptor function in MDD, we administered the $5-\mathrm{HT}_{1 \mathrm{a}}$ agonist and dopamine (DA) antagonist buspirone as a neuroendocrine challenge agent to a group of patients with MDD and a group of healthy controls. Buspirone was chosen as the neuroendocrine challenge agent because it does not bind to other 5-HT receptors in physiologic concentrations and is well tolerated as a challenge agent in humans. Busiprone's drawback as a challenge agent is that it does bind to DA receptors as well as 5-HT receptors; it is possible that at least part of the neuroendocrine effects of buspirone are due to its effects on DA. The hypothesis of this study was that patients with MDD would show a blunted prolactin (postsynaptic) response compared to control subjects.

\section{METHODS}

Thirteen male patients with a DSM-III-R diagnosis of MDD and 10 healthy male controls were selected using the Structured Clinical Interview for DSM-III-R (Spitzer et al. 1990). All subjects received a thorough medical evaluation including a review of systems and a physical examination, which showed no evidence of central nervous system disease. Routine blood work, thyroid function tests, and human immunodeficiency virus test were all normal. No depressed subject was administered any psychotropic medications for at least 2 weeks prior to neuroendocrine challenge, except for occasional low-dose benzodiazepines or chloral hydrate as hypnotic agents. No depressed subject had taken depot neuroleptics, fluoxetine, and cloimipramine for at least 6 months prior to the neuroendocrine challenge. No depressed subject met DSM-III-R criteria for any other axis I disorder. No subject met criteria for alcohol or drug dependence within the 6 months prior to the neuroendocrine challenge. Eight of the 13 patients were inpatients at the time of the neuroendocrine challenge, and five were outpatients. To be entered in the study, all subjects had a score of at least 15 on the 17-item Hamilton Depression Rating Scale (HDRS-D) (Hamilton et al. 1960) at screening.

All subjects received two neuroendocrine challenges separated by an interval of at least 48 hours. Buspirone and placebo challenges were administered in a random sequence. Each challenge consisted of a single dose of either buspirone $(0.4 \mathrm{mg} / \mathrm{kg})$ or placebo administered orally. All subjects were on a low monoamine diet for 72 hours prior to each challenge. Subjects and staff administering the rating scales were blinded to the medication condition. The subjects were given a standard light breakfast at 9:00 AM consisting of a can of Ensure (Ross Laboratories, Columbus, $\mathrm{OH}$ ) prior to the challenge drug. Buspirone is more readily absorbed with food; thus, the subjects were not fasting. It was also thought best not to fast subjects to minimize "stressful nausea," which has been reported to increase serum prolactin in healthy controls (Anderson et al. 1992). All subjects were kept supine and awake for the duration of the challenge. On the day of the neuroendocrine challenge, the subjects entered the Psychobiology Laboratory of the Dallas VA Medical Center Hospital prior to 8:30 AM. Shortly after the patient arrived, a catheter was inserted intravenously and an infusion of normal saline was initiated at the lowest rate necessary to keep the infusion open. One hour and 45 minutes after the insertion of the catheter, the first blood sample was drawn through a three-way stop cock to measure serum prolactin. Approximately $1 \mathrm{cc}$ of blood was withdrawn and discarded prior to obtaining samples that were used in the study to eliminate any dilution effects of the normal saline. Two hours after the 
insertion of the catheter, the second baseline prolactin and cortisol levels were measured. After the second baseline blood drawing, the subject received the challenge drug consisting of either placebo or $0.4 \mathrm{mg} / \mathrm{kg}$ of buspirone. There was a 2-hour delay after insertion of the catheter to allow for stabilization of hormone levels (Davis et al. 1985). Blood drawing was repeated at 15minute intervals from 10:45 AM till 1:00 PM. The schedule for blood drawing included the period of increase in neuroendocrine parameters in previous studies (Meltzer et al. 1983). Approximately $10 \mathrm{cc}$ of blood was drawn at each time point. The total amount of blood drawn did not exceed $150 \mathrm{cc}$ per challenge day or 500 cc per month. The subject's blood pressure and pulse were measured before and after each challenge.

\section{Assays Analysis}

Prolactin measurements were made on serum. Prolactin was chosen instead of other hormones, such as cortisol or ACTH because in our experience, the prolactin response to buspirone is the most robust (FG Moeller, unpublished data). Samples were centrifuged, and serum was separated and frozen within 1 hour after the blood was drawn. After separation, samples were stored in a refrigerator at $-30^{\circ} \mathrm{C}$ until analysis. Samples were analyzed within 2 months of collection by a technician blind to subject diagnosis. Prolactin was determined in serum using a "coated tube" radio immunoassay with a monoclonal prolactin antibody immobilized on the tube wall.

Subject samples are incubated with ${ }^{125}$ I-labeled prolactin in antibody coated tubes for 2 hours with rotation $(180 \pm 10 \mathrm{rpm})$ after which the tubes are decanted to separate free prolactin from antibody-bound prolactin, which is counted in a gamma counter. This assay is usable over a broad range ( 0 to $100 \mathrm{ng} / \mathrm{ml}$ ) and has a sensitivity of $0.3 \mathrm{ng} / \mathrm{ml}$. Coefficients of variation are typically $6 \%$ at $8 \mathrm{ng} / \mathrm{ml}, 5 \%$ at $20 \mathrm{ng} / \mathrm{ml}$, and $5 \%$ at 45 $\mathrm{ng} / \mathrm{ml}$.

Buspirone assays were done according to a modification of the method of Franklin (1990), using gepirone as an internal standard. The resolution and sensitivity were determined by spiked plasma samples at 1.0, 5.0, and $10.0 \mathrm{ng} / \mathrm{ml}$. The samples were observed to be linear and proportional in this range. The interassay variability was $8.6 \%$, and the recovery of buspirone $(2.5$ $\mathrm{ng} / \mathrm{ml}$ ) ranged from $70 \%$ to $77 \%$.

\section{Statistical Analysis}

Between group differences in mean age, buspirone levels, and HDRS-D scores were analyzed using the Student's $t$-test. The relationship between HDRS-D scores and peak prolactin levels within the depressed subjects
Table 1. Mean Age, HDRS Scores, and Prolactin Response in Depressed Patients and Healthy Controls

\begin{tabular}{lccc}
\hline Group & Age & HDRS-D & $\begin{array}{c}\text { Corrected Peak } \\
\text { Prolactin Levels }\end{array}$ \\
\hline Control & $37.8 \pm 12.4$ & $0.3 \pm 0.5$ & $14.59 \pm 10.32$ \\
MDD & $45.8 \pm 8.6$ & $18.1 \pm 5.1^{\star \star \star}$ & $3.27 \pm 2.68^{\star \star}$ \\
\hline
\end{tabular}

${ }^{\star \star \star} p<.001,{ }^{\star \star} p<.01$, MDD vs. controls.

was analyzed using a regression analysis. Repeatedmeasures analysis of variance (ANOVA) was performed on the prolactin levels over time to test the primary hypothesis that the prolactin response to buspirone was different between the two diagnostic groups. Two depressed subjects and one control were dropped from the repeated-measures analysis because of missing prolactin levels at one or two time points. The prolactin response to buspirone was placebo corrected by subtracting the prolactin response to placebo from the prolactin response to buspirone. This was repeated for all time points in both depressed patients and controls. Prolactin levels were placebo corrected to adjust for any nonspecific effects on prolactin secretion, such as food.

Because there was a nonsignificant trend for a difference in age between depressed subjects and controls, the influence of age was first examined by including age, group, and the age-group interaction in the ANOVA model.

This was done to test the underlying assumption of homogeneity of within group regression. Repeatedmeasures analysis of covariance (ANCOVA) was performed to determine if age was a significant covariate for prolactin response to buspirone.

\section{RESULTS}

Depressed patients were significantly more depressed than controls at the time of the first neuroendocrine challenge as measured by the 17-item HDRS-D ( $t=$ $10.88, p<.0001)$. There was a nonsignificant trend for age to differ between the depressed and control groups $(t=1.84, p=.08)$, see Table 1 .

Using repeated-measures ANOVA, there was a significant main effect of group on the prolactin response between depressed patients and controls over time $(F[1,18]=9.4 ; p=.007$; Figs. 1 and 2$)$. Bonferronicorrected post-hoc analyses revealed a significant difference between the prolactin response of depressed patients and controls at 11:30 AM, 11:45 AM, 12:00 noon, 12:15 PM, 12:30 PM, 12:45 PM, and 1:00 PM (Fig. 3). Because there was no significant interaction between age and group over time, $(F[1,11]=0.417 ; p=.947)$, a repeated-measures ANCOVA with age as the covari- 


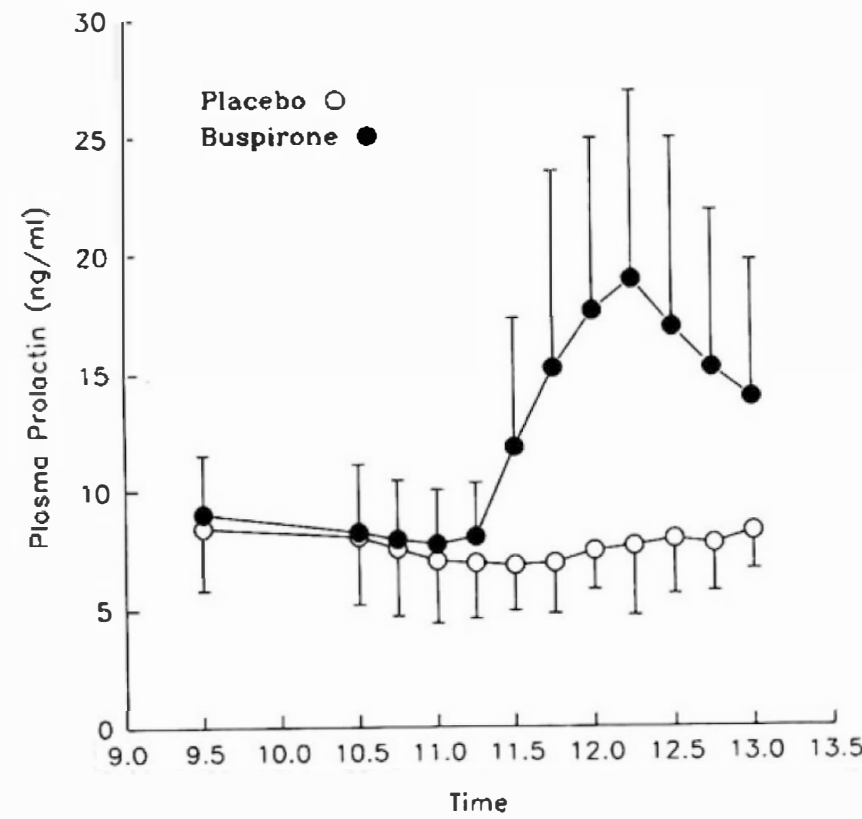

Figure 1. Placebo-and buspirone-induced prolactin response in healthy controls $(n=10)$. Buspirone or placebo were administered immediately after the 10:30 AM sample was obtained.

ate was performed. There was no significant interaction between age and response to buspirone over time by repeated-measures ANCOVA with age as the covariate $F[1,11]=0.879 ; p=.562$. Using ANOVA, there was a significant difference between the depressed pa-

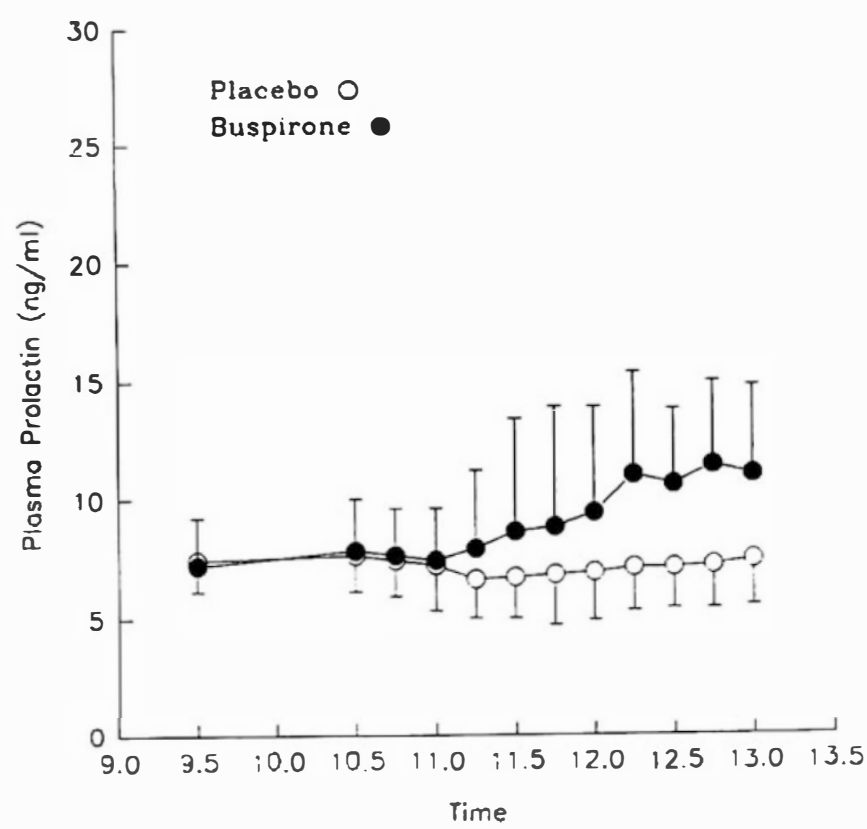

Figure 2. Placebo-and buspirone-induced prolactin response in patients with MDD $(n=13)$. Buspirone or placebo were administered immediately after the 10:30 AM sample was obtained.

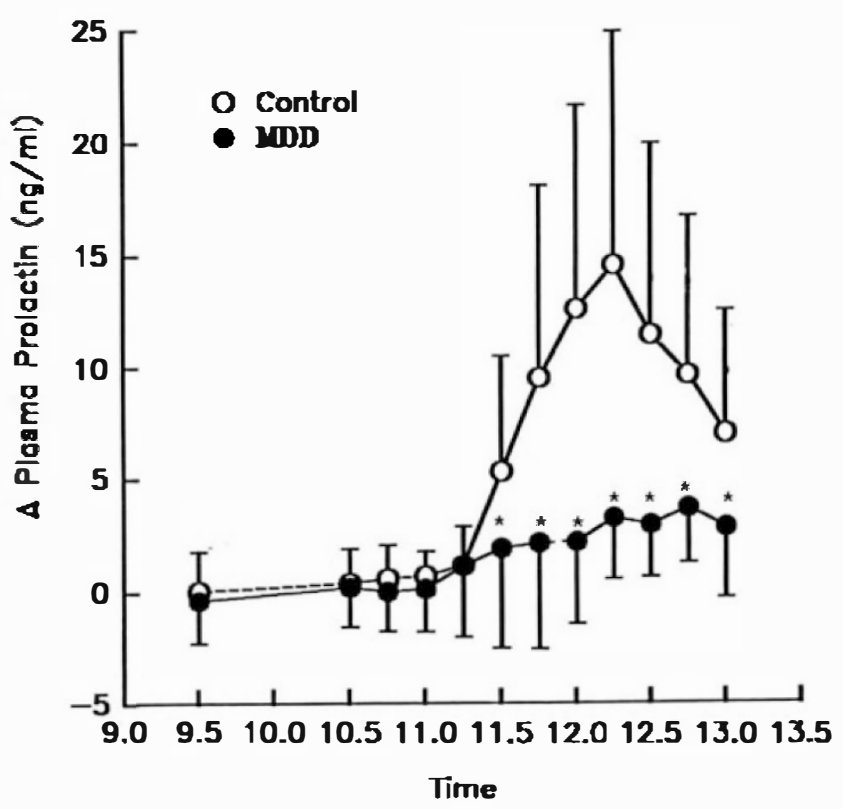

Figure 3. Placebo corrected prolactin response (delta prolactin) to buspirone in depressed subjects and healthy controls. Prolactin responses were placebo corrected by subtracting the placebo-induced rise in prolactin from the buspirone-induced rise in prolactin at the corresponding time point ${ }^{*} p<.05$, MDD vs. controls).

tients and controls in placebo corrected peak prolactin response $(F[1,21]=14.6 ; p=.001)$.

To determine the relationship between behavioral symptoms and neuroendocrine response within depressed subjects, the placebo corrected peak prolactin level was used in a regression analysis with HDRS-D scores. There was no significant relationship between prolactin level and severity of depression as measured by the HDRS-D $\left(r^{2}=0.035 ; p=.54\right)$. Patients were then subdivided into DSM-III-R melancholic $(n=5)$ and nonmelancholic $(n=8)$ subtypes, with the hypothesis that the melancholic subtype would have significantly lower neuroendocrine response, as has been reported previously (Anderson et al. 1992).

Melancholic patients appeared to have a lower peak prolactin $(1.48 \pm 1.82)$ than nonmelancholic patients $(4.38 \pm 2.59)$, and the three lowest peak prolactin levels were in patients with melancholic depression. Using a $t$-test to compare the mean prolactin level between the melancholic and nonmelancholic patients, there was a nonsignificant trend for the melancholic group to have a lower peak prolactin level $(t=-2.18 ; p=.052)$. However, this trend was not present in post-hoc contrasts when using an ANOVA that included the control group $(F[1,20]=0.509 ; p=.484$; Fig. 4$)$.

Because of the previous report of a link between neuroendocrine response to a 5-HT challenge agent and history of suicidal behavior (Coccaro et al. 1989), we examined the relationship between history of sucidial 


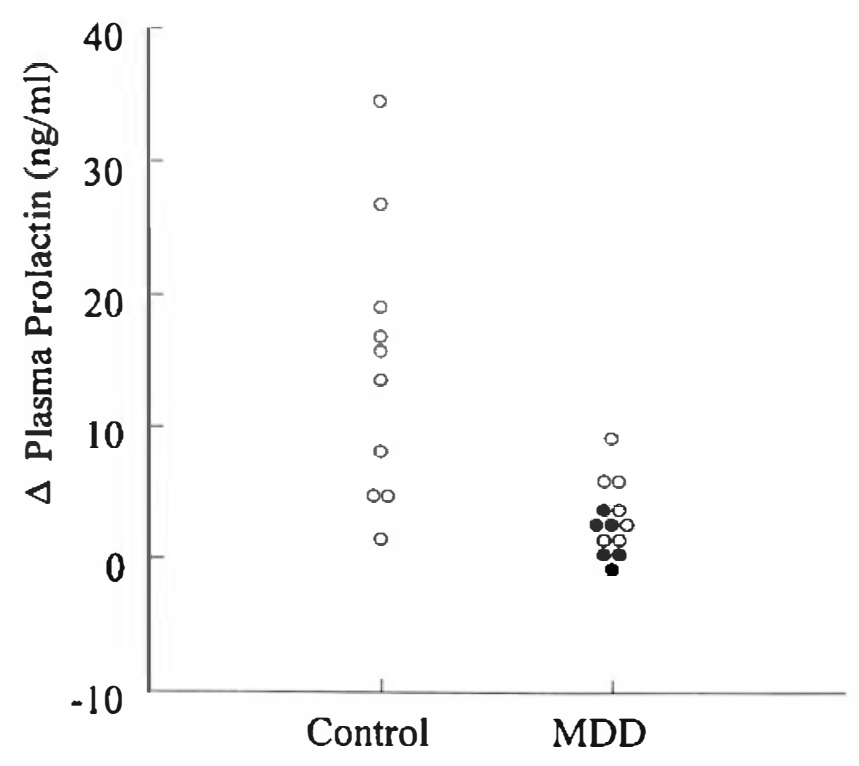

Figure 4. Placebo corrected peak prolactin response (delta prolactin) in depressed subjects and healthy controls. Filled circles indicate depressed subjects who met DSM-III-R criteria for melancholia.

behavior (defined as positive history of suicide attempt as determined from patient interview or chart review) and peak prolactin response. When patients were subdivided into positive history of suicidal behavior and nohistory of suicidal behavior, there was no significant difference in peak prolactin response between the two groups $(F[1,20]=0.002 ; p=.97)$.

To determine if the blunted prolactin response to buspirone in the patient group was due to decreased absorption of buspirone, we compared the area under the curve (AUC) for buspirone blood levels between depressed patients and controls. Depressed patients had significantly higher buspirone blood levels (AUC $623.4 \pm 519.0)$ than controls (AUC $241.5 \pm 99.0)(t=$ $-2.28 ; p<.05)$. The relationship between buspirone blood levels and peak prolactin response was determined by the Pearson correlation for all subjects and for depressed and control groups individually. For the study population as a whole, there was no significant correlation between buspirone blood level and peak prolactin response $(r=-0.04 ; p=.85)$. There was also no correlation between buspirone blood level and prolactin response in controls $(r=0.32 ; p=.38)$. However, there was a significant correlation between buspirone blood level and peak prolactin response within the group of depressed subjects $(r=0.56 ; p=.05$; Fig. 5).

\section{DISCUSSION}

Aspredicted, depressed patients had a blunted prolactin response to buspirone compared to controls. The prolactin response did not correlate with the severity of illness as measured by HDRS-D scores within the depressed patients. Three of the five depressed patients who met DSM-III-R criteria for melancholia had the lowest peak prolactin response, although the difference between melancholic and nonmelancholic patients did not reach statistical significance, probably due to the small sample size. There was a trend difference in age between depressed and control groups; however, age did not appear to significantly affect results in an ANCOVA.

Because of the fact that depressed patients did not have a lower serum buspirone level than controls, the blunted prolactin response in depressed patients cannot be explained by absorption or metabolism of buspirone. It is unclear why the buspirone level was higher in the depressed patients, as both controls and patients were given $0.4 \mathrm{mg} / \mathrm{kg}$. Although all patients meet DSMIII-R criteria for MDD at the time of the study and had at least a score of 15 to be included in the study, it should be kept in mind that the mean HDRS-D score for the patients was relatively low (18). Because of the low mean HDRS-D scores, these results should not be generalized to more severely depressed patients. This study supports the previous findings of Lesch et al. (1991) of a blunted ACTH response using the 5-HT1a agonist ipsapirone and points to a postsynaptic $5-\mathrm{HT}_{1 \mathrm{a}}$ deficit in patients with MDD.

There are two other possible explanations for our findings. It is possible that patients with MDD have a deficit in prolactin secretion at the pituitary level, and thus any neuroendocrine challenge agent would find a blunted response in MDD compared to controls. This is unlikely in light of recent research that found no blunting in prolactin response in MDD patients compared to controls using thyrotropin-releasing hormone, which acts directly on the pituitary to release prolactin (Anderson et al. 1992).

It is also possible that the neuroendocrine effects of buspirone are secondary to buspirone's effects as a dopamine antagonist.

Heninger and colleagues (1989) studied the effects of the DA antagonist haloperidol and several 5-HT agonists including buspirone on prolactin secretion in rhesus monkeys. Based on the relative potency of DA receptor antagonism for the drugs studied, they concluded that DA inhibition is relatively more important than 5-HT stimulation in the control of prolactin secretion. Other investigators have studied the role of 5-HT and DA in buspirone-induced prolactin secretion by using pretreatment with the $5 \mathrm{HT}_{1 \mathrm{a}}$ and the $\beta$-adrenergic antagonist pindolol. Anderson and Cowen (1992) found that pindolol pretreatment reduced the prolactin response to buspirone but did not significantly diminish the overall amount of prolactin secreted (as measured by AUC) in healthy controls. These authors interpreted 


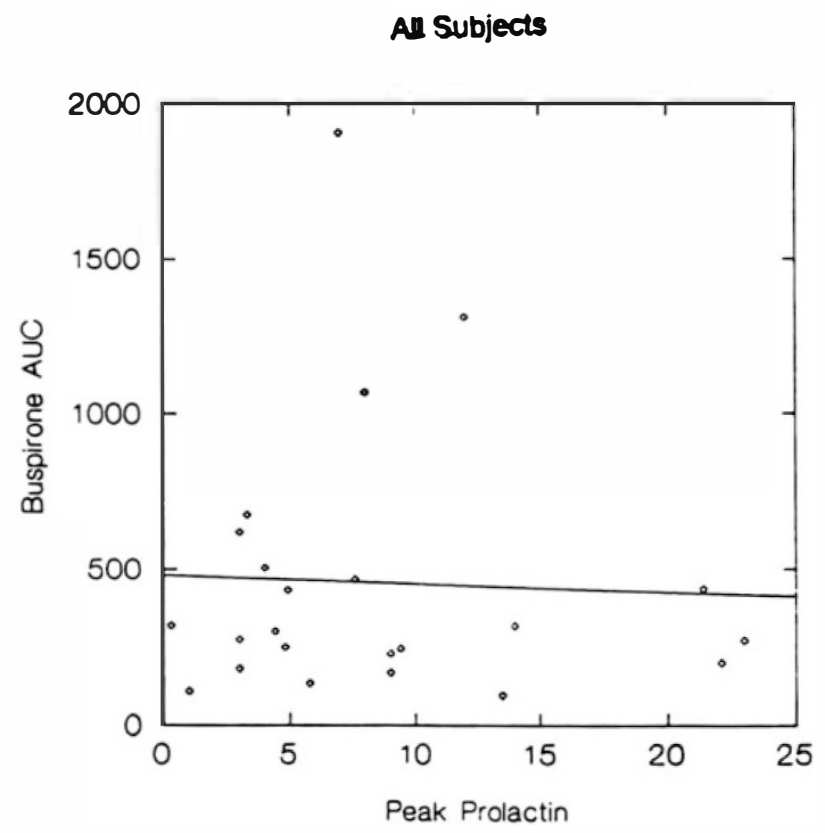

Controls

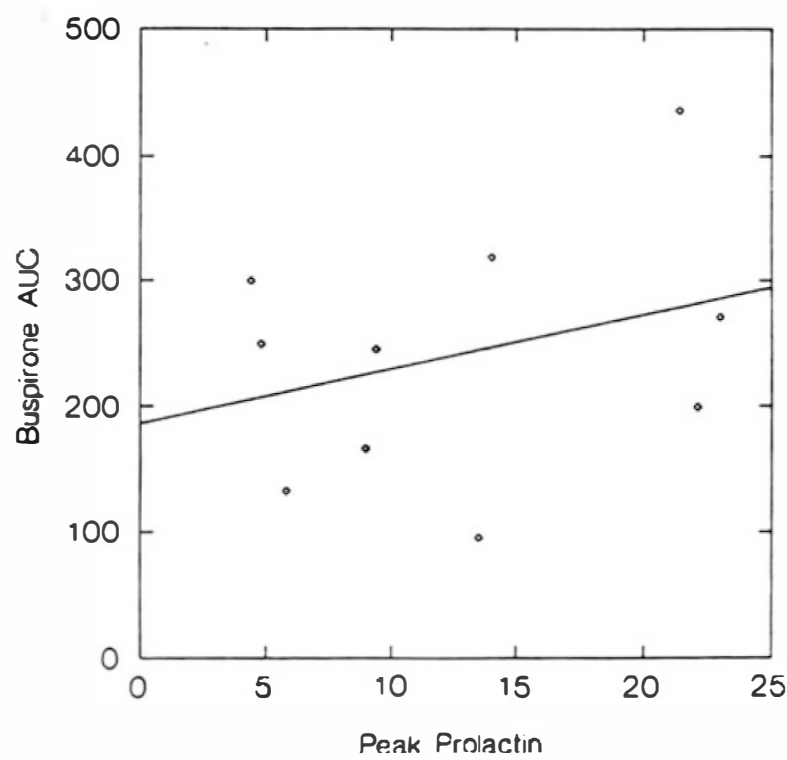

Depressed Patients

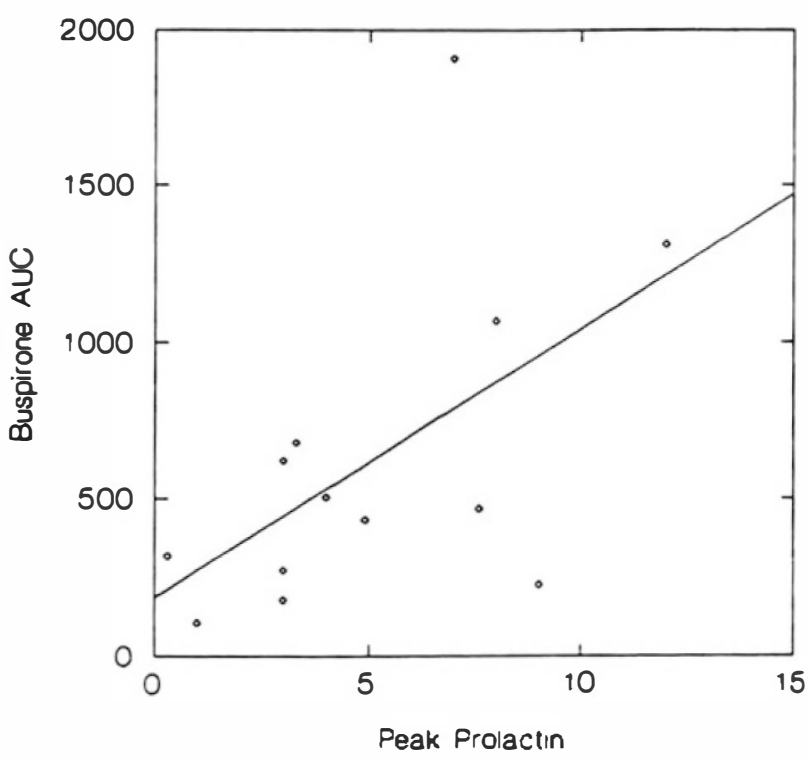

Figure 5. Correlation between buspirone levels and peak prolactin response in all subjects, depressed patients, and healthy controls.

their results as consistent with the prolactin response to buspirone being mediated both by $5 \mathrm{HT}_{1 \mathrm{a}}$ agonist and DA antagonist effects or possible pharmacokinetic interactions between buspirone and pindolol. Other researchers find no effect of pretreatment with the $5-\mathrm{HT}_{\mathrm{la}}$ antagonist pindolol on prolactin secretion induced by buspirone (Meltzer et al. 1992). Although some studies (Meltzer et al. 1992) report that the neu- roendocrine effects of buspirone in humans are not blocked by pindolol pretreatment, this does not necessarily mean that the neuroendocrine effects are not mediated by 5 -HT. Other investigators have reported that pindolol is a mixed agonist/antagonist at the $5-\mathrm{HT}_{1 \mathrm{a}}$ receptor (Hjorth and Carlsson 1986) and that behavioral effects of 5- $\mathrm{HT}_{1 \mathrm{a}}$ agonists are not reversed by pindolol in mice (Sanchez et al. 1993). We have also 
examined the effect of pretreatment with pindolol on the neuroendocrine effects of buspirone in normal controls. We found that pindolol did not block the increase in hormone release induced by buspirone, in fact, pindolol itself increased ACTH and cortisol, further supporting the hypothesis that pindolol is not a pure $5-\mathrm{HT}_{1 \mathrm{a}}$ antagonist (FG Moeller, unpublished data).

Although it is possible that the buspirone-induced prolactin response may be secondary to effects on DA, buspirone does have a high affinity for the $5-\mathrm{HT}_{1 \mathrm{a}}$ receptor subtype (Peroutka 1985; Yocca et al. 1986, 1990), where buspirone acts as a partial agonist (Yocca et al. 1986). Buspirone also lacks the behavioral, or motor, effects common to DA antagonists. Buspirone has been found to increase serum ACTH and cortisol and to decrease temperature in rats and humans (Cowen et al. 1990; Koenig et al. 1988). These effects are similar to the effects of 8-OH-DPAT (the prototypical 5-HT $1 \mathrm{a}$ receptor agonist) in rats (Gilbert et al. 1988; Aulakh et al. 1988). Buspirone also increases serum prolactin in both laboratory animals and man (Meltzer et al. 1982, 1983; Cowen et al. 1990), similar to the 5-HT-releasing agent fenfluramine (Serri et al. 1987; Coccaro et al. 1988; Siever et al. 1984; Quattrone et al. 1983), and the 5-HT precursors L-tryptophan and 5-HTP (Lamberts et al. (1978; MacIndoe et al. 1973).

The fact that the buspirone-induced prolactin response is not blocked by pindolol and the fact that other serotonin agonists do not appear to induce the degree of elevation in prolactin that buspirone does leads to the conclusion that at least part of the prolactin response induced by buspirone is probably mediated by buspirone's effects as a DA antagonist. However, due to the lack of a selective $5-\mathrm{HT}_{1 \mathrm{a}}$ antagonist and the fact that buspirone does not exhibit the behavioral effects of other DA antagonists, the exact relationship between 5-HT, DA, and the prolactin response to buspirone remains undetermined.

A relationship between DA and MDD was postulated over 15 years ago (Randrup et al. 1975). The strongest biochemical evidence for this relationship comes from studies examining cerebrospinal fluid homovanillic acid. Several studies find decreased cerebrospinal fluid homovanillic acid in patients with depression (Goodwin et al. 1973; Randrup et al. 1975; van Praag et al. 1975). However, because this abnormality is most pronounced in patients with psychomotor retardation (Kapur and Mann 1992), it is unclear whether low cerebrospinal fluid homovanillic acid is related to depression itself or to accompanying psychomotor retardation. The questions regarding the relationship between DA and depression are compounded by the fact that most studies using DA agonists as neuroendocrine challenge agents do not find evidence of abnormal DA function in depression (Costain et al. 1982; Christie et al. 1982, Balldin et al. 1982).
In summary, we report a blunted prolactin response to buspirone neuroendocrine challenge in patients with MDD compared to healthy controls.

The results of this study should be viewed as preliminary, in light of the small sample size, and the possible influence of buspirone's effects on DA. However, in light of other studies that find evidence of a 5-HT 1 a deficit in MDD, this study does support further investigation into the specific role of the presynaptic and postsynaptic $5-\mathrm{HT}_{1 \mathrm{a}}$ receptors in the etiology of MDD.

\section{ACKNOWLEDGMENTS}

This work was supported by the Department of Veterans Affairs and MHCRC Center Grant No. MH41115. We thank Jennifer Gilreath and Melissa Moeller for technical assistance and Stephanie Todd and Michelle Foy for secretarial support.

\section{REFERENCES}

Amsterdam JD (1992): Gepirone, a selective serotonin (5HT(1A)) partial agonist in the treatment of major depression. Prog Neuropsychopharmacol Biol Psychiatry 16:271-280

Anderson IM, Cowen PJ (1992): Effect of pindolol on endocrine and temperature responses to buspirone in healthy volunteers. Psychopharmacology 106:428-432

Anderson IM, Ware CJ, Davis JMD, Cowen PJ (1992): Decreased 5-HT-mediated prolactin release in major depression. Br J Psychiatry 160:372-378

Aulakh CS, Wozniak KM, Haas M (1988): Food intake, neuroendocrine and temperature effects of 8-OH-DPAT in the rat. Eur J Pharmacol 147:343-350

Balldin J, Granenis AK, Lindstedt G, Modigh K, Walinder $\mathrm{J}$ (1982): Neuroendocrine evidence for increased responsiveness of dopamine receptors in humans following electroconvulsive therapy. Psychopharmacology 76:371-376

Blier P, De Montigny C. Chaput Y (1990): A role for the serotonin system in the mechanism of action of antidepressant treatments: Preclinical evidence. J Clin Psychiatry 51 (Suppl):14-20

Cervo L, Samanin R (1987): Evidence that dopamine mechanisms in the nucleus accumbens are selectively involved in the effect of desipramine in the forced swimming test. Neuropharmacology 26:1469-1472

Charney DS, Heninger GR, Sternberg DE (1984): Serotonin function and mechanism of action of antidepressant treatment: Effects of amitriptyline and desipramine. Arch Gen Psychiatry 41:359-365

Christie JE, Whalley LJ, Brown NS, Dick H (1982): Effect of ECT on the neuroendocrine response to apomorphine in several depressed patients. Br JPsychiatry 140:268-273

Coccaro EF, Siever LJ, Kourides IA, Adan F, Campbell G, Davis KL (1988): Central serotonergic stimulation by fenfluramine challenge does not affect plasma thyrotropin-stimulating hormone levels in man. Neuroendocrinology 47:273-276

Coccaro EF, Siever LJ, Klar HM, Maurer G, Cochraine K, Cooper TB, Mohs RC, Davis KL (1989): Serotonergic 
studies in patients with affective and personality disorders. Correlates with suicidal and impulsive aggressive behavior. Arch Gen Psychiatry 46:587-599

Coppen AJ (1967): The biochemistry of affective disorder. Br J Psychiatry 113:1237-1264

Costain DW, Gelder MW, Cowen PJ, Grahame-Smith DG (1982): Electroconvulsive therapy and the brain: Evidence for increased dopamine mediated responses. Lancet 2:400-404

Cowen PJ, McCance SL, Gelder MG, Grahame-Smith DG (1990): Effect of amitriptyline on endocrine responses to intravenous L-tryptophan. Psychiatry Res 31:201-208

Davis BM, Davis KL, Mohs RC, Mathe AA (1985): Evaluating prolactin response to dopamine agonists in schizophrenia. Methodological problems. Arch Gen Psychiatry 42:259-264

Franklin M (1990): Determination of plasma buspirone by high-performance liquid chromatography with coulometric detection. J Chromatogr 526:590-596

Gilbert F, Brazell C, Trickelbank MD, Stahl SM (1988): Activation of the 5-HT1a receptor subtype increases rat $\mathrm{ACTH}$ concentration. Eur J Pharmacol 147:431-439

Golden RN, Ekstrom D, Brown TM, Ruegg R, Evans DL, Haggerty JJ, Garbutt JC, Pederson CA, Mason GA, Browne J, Carson SW (1992): Neuroendocrine effects on intravenous clomipramine in depressed patients and healthy subjects. Am J Psychiatry 149:1168-1175

Goodwin FK, Post RM, Dunner DL, Gordon EK (1973): Cerebrospinal fluid amine metabolites in affective illness. The probenecid technique. Am J Psychiatry 130:73-79

Goodwin GM, Green AR (1985): A behavioral and biochemical study in mice and rats of putative selective agonists and antagonists for 5-HT1 and 5-HT2 receptors. Br J Pharmacol 84:743-753

Hamilton M (1960): A rating scale for depression. J Neurol Neurosurg Psychiatry 23:56-62

Heninger GR, Charney DS, Sternberg DE (1984): Serotonergic function in depression: Prolactin response to intravenous tryptophan in depressed patients and healthy subjects. Arch Gen Psychiatry 41:398-402

Heninger GR, Charney DS, Price LH, Delgado P, Woods S, Goodman W (1989): Effects of serotonergic agonists on neuroendocrine responses of rhesus monkeys and patients with depression and anxiety disorders. Psychopharmacology Ser 7:94-104

Hjorth S, Carlsson A, (1986): Is pindolol a mixed agonist/ antagonist at central serotonin (5-HT) receptors? Eur J Pharmacol 129:131-138

Kapur S, Mann JJ (1992): Role of the dopaminergic system in depression. Biol Psychiatry 32:1-17

Koenig JI, Meltzer HY, Gudelsky GA (1988): 5-Hydroxytryptamine-mediated effect of buspirone, gepirone and ipsapirone. Pharmacol Biochem Behav 29:711-715

Lamberts SWJ, MacLeod RM (1978): The interaction of the serotonergic and dopaminergic systems on prolactin secretion in the rat. Endocrinology 45:287-295

Lesch KP (1991): 5- HT $_{1 \mathrm{~A}}$ receptor responsivity in anxiety disorders and depression. Prog Neuropsychopharmacol Biol Psychiatry 15:723-734
Lesch KP, Disselkamp-Tietze J, Schmidtke A (1990): 5-HT-1a receptor function in depression: Effect of chronic amitriptyline treatment. J Neural Transm 80:157-161

Lichtenberg P, Shapira B, Gillon D, Kindler S, Cooper TB, Newman ME, Lerer B (1992): Hormone responses to fenfluramine and placebo challenge in endogenous depression. Psychiatry Res 43:137-146

MacIndoe JH, Turkington RW (1973): Stimulation of human prolactin secretion by intravenous infusion of L-tryptophan. J Clin Invest 52:1972-1978

Martin P, Beninger R, Hamon M, Puech AJ (1990): Antidepressant-like action of 8-OH-DPAT, a 5-HT1A agonist, in the learned helplessness paradigm: Evidence for a postsynaptic mechanism. Behav Brain Res 38:135144

Meltzer HY, Simonovic M, Fang VS (1982): Effect of buspirone on rat plasma prolactin levels and striatal dopamine turnover. Psychopharmacology 78:49-53

Meltzer HY, Flemming R, Robertson A (1983): The effect of buspirone on prolactin and growth hormone secretion in man. Arch Gen Psychiatry 40:1099-1102

Meltzer HY, Lee HS, Nash JF (1992): Effect of buspirone on prolactin secretion is not mediated by $5-\mathrm{HT}-1 \mathrm{~A}$ receptor stimulation. Arch Gen Psychiatry 49:163 (Letter)

MitchellP, Smythe G (1990): Hormonal responses to fenfluramine in depressed and control subjects. J Affect Disord 19:43-51

Pandey SC, Isaac L, Davis JM, Pandey GN (1991): Similar effects of treatment with desipramine and electroconvulsive shock on 5-hydroxytryptamine-1A receptors in rat brain. Eur J Pharmacol 202:221-225

Peroutka SJ (1985): Selective interactions of novel anxiolytics with 5-HT1A receptors. Biol Psychiatry 20:971-979

Peroutka SJ, Snyder SH (1980): Long-term antidepressant treatment decreases spiroperidol-labeled serotonin receptor binding. Science 210:88:90

Quattrone A, Tedeschi G, Aguglia F, Scopacasa F, DiRenzo GF, Annunziato L (1983): Prolactin secretion in man: A useful tool to evaluate the activity of drugs on central 5-hydroxytryptaminergic neurons. Studies with fenfluramine. Br J Clin Pharmacol 16:471-475

Randrup A, Munkvad I, Fog R, Gerlach J, Molander L, Kjellberg B, Scheel-Krüger J (1975): Mania, depression, and brain dopamine. In Essman WB, Valzelli L (eds), Current Developments in Psychopharmacology. New York: Spectrum Publications, pp 207-229

Rausch JL, Ruegg R, Moeller FG (1990): Gepirone as a 5HT1a agonist in the treatment of major depression. Psychopharmacol Bull 26:169-171

Reimherr FW, Chouinard G, Cohn CK, Cole JO, Itil TM, Lapierre YD, Masco HL, Mendels J (1990): Antidepressant efficacy of sertraline: A double-blind, placebo- and amitriptyline-controlled, multicenter comparison study in outpatients with major depression. J Clin Psychiatry 51:18-27

Rickels K, Amsterdam JD, Clary C, Puzzuoli G, Schweizer E (1991): Buspirone in major depression: A controlled study. J Clin Psychiatry 52:34-38

Sanchez C, Arnt J, Hyttel J, Moltzen EK (1993): The role of 
serotonergic mechanisms in inhibition of isolation-induced aggression in male mice. Psychopharmacology 110: 53-59

Serri O, Rasio E (1987): The effect of $d$-fenfluramine on anterior pituitary hormone release in the rat: In vivo and in vitro studies. Can J Physiol Pharmacol 65:2449-2453

Shapira B, Lerer B, Kindler S, Lichtenberg P, Gropp C, Cooper T, Calev A (1992a): Enhanced serotonergic responsivity following electroconvulsive therapy in patients with major depression. Br J Psychiatry 160:223-229

Shapira B, Yagmur MJ, Gropp C, Newman M, Lerer B (1992b): Effect of clomipramine and lithium on fenfluramineinduced hormone release in major depression. Biol Psychiatry 31:975-983

Siever LJ, Murphy DL, Slater S, de la Vega E, Lipper S (1984): Plasma prolactin changes following fenfluramine in depressed patients compared to controls: An evaluation of central serotonergic responsivity in depression. Life Sci 34:1029-1039

Spitzer RL, Williams JBW, Gibbon M, First MB (1990): Struc- tured Clinical Interview for DSM-III-R. Washington, DC, American Psychiatric Press

van Praag HM, Korf J, Lakke JPWF, Schut T (1975): Dopamine metabolism in depressions psychoses, and Parkinson's disease: The problem of the specificity of biological variables in behavior disorders. Psychol Med 5:138146

Wieland S, Lucki I (1990): Antidepressant-like activity of 5-HT-1a agonists measured with the forced swim test. Psychopharmacology 101:497-504

Yocca FD (1990): Neurochemistry and neurophysiology of buspirone and gepirone: interactions at presynaptic and postsynaptic 5-HT1a receptors. J Clin Psychopharmacol 10:6S-12S

Yocca FD, Hyslop DK, Taylor DP (1986): Buspirone and gepirone: partial agonists at the 5-HT1a receptor linked to adenylate cyclase in rat and guinea pig hippocampal preparations. Fed Proc 45:436 